\title{
Fake news colocam a vida em risco: a polêmica da campanha de vacinação contra a febre amarela no Brasil
}

\author{
Fake News put human life at risk: the controversy of the yellow fever \\ vaccination campaign in Brazil
}

\author{
Fake News ponen en riesgo la vida: la controversia de la campaña de \\ vacunación contra la fiebre amarilla en Brasil
}

\author{
Adriana Teixeira ${ }^{1, a}$ \\ drikkis@uol.com.br | https://orcid.org/0000-0001-9900-5650 \\ Rogério da Costa ${ }^{1, b}$ \\ rogcosta@pucsp.br | https://orcid.org/0000-0002-6807-4263 \\ ${ }^{1}$ Pontifícia Universidade Católica de São Paulo. São Paulo, SP, Brasil \\ a Mestrado em Comunicação e Semiótica pela Pontifícia Universidade Católica de São Paulo. \\ ${ }^{B}$ Doutorado em História da Filosofia pela Université de Paris IV - Sorbonne.
}

\section{Resumo}

Este artigo faz a leitura das notícias falsas que circulam conteúdo sobre saúde pública em redes digitais e aplicativos de troca de mensagens. Para enumerar os argumentos utilizados pelos divulgadores de fake news na disputa pela enunciação da verdade, no campo do discurso, os autores escolheram a campanha de vacinação contra a febre amarela, lançada em um surto da doença no Brasil, no final de 2016. Selecionamos os textos de posts e áudios que se multiplicaram no WhatsApp, especificamente no ano de 2018, para a análise ancorada nas teses sobre produção de verdade e poder de Michel Foucault e de Nikolas Rose. Iniciamos, assim, uma reflexão sobre a ação das fake news em defesa da vida e que, ao mesmo tempo, colocam a vida em risco. A Organização Mundial da Saúde já aponta as fake news como uma das responsáveis pela baixa nos níveis internacionais de imunização.

Palavras-chave: Fake news; Saúde; Comunicação; Biopolítica; Febre amarela; Vacinação. 


\begin{abstract}
This article analyses the fake news that spread contents of public health using digital networks and crossplatform messaging applications. To list the arguments used by those people whom spread fake news to dispute the utterance of the truth, in the discourse field, the authors have chosen the yellow fever vaccination campaign, launched in the outbreak of the disease in Brazil, in late 2016. We selected the texts of posts and audios that multiplied via WhatsApp, specifically in 2018, for analysis based on the theses on the production of truth and power by Michel Foucault and Nikolas Rose. Thus, we started a reflection on the action of fake news in defense of life while themselves put many lives at risk. The World Health Organization already points out fake news as one of the factors responsible for the drop in international levels of immunization.
\end{abstract}

Keywords: Fake news; Health; Communication; Biopolitics; Yellow fever; Vaccination.

\title{
Resumen
}

Este artículo hace un análisis de las fake news que difunden contenido sobre salud pública por medio de redes digitales y aplicaciones de mensajería. Para enumerar los argumentos utilizados por las personas que hacen la divulgación de las fake news en la disputa por la expresión de la verdad, en el campo del discurso, los autores eligieron la campaña de vacunación contra la fiebre amarilla, lanzada en el brote de la enfermedad en Brasil, a fines de 2016. Seleccionamos los textos de publicaciones y audios que se multiplicaron en el WhatsApp, especialmente en 2018, para el análisis basado en las tesis sobre la producción de verdad y poder de Michel Foucault y de Nikolas Rose. Comenzamos así a reflexionar sobre la acción de las fake news en defensa de la vida y que al mismo tiempo la ponen en riesgo. La Organización Mundial de la Salud ya señala las fake news como uno de los factores responsables de la bajada de los niveles internacionales de inmunización.

Palabras clave: Fake news; Salud; Comunicación; Biopolítica; Fiebre amarilla; Vacunación.

Este artigo compõe o dossiê Fake News e Saúde.

Contribuição dos autores:

Concepção e desenho do estudo: Adriana Teixeira.

Aquisição, análise ou interpretação dos dados: Adriana Teixeira, Rogério da Costa.

Redação do manuscrito: Adriana Teixeira.

Revisão crítica do conteúdo intelectual: Adriana Teixeira, Rogério da Costa.

Declaração de conflito de interesses: não há.

Fontes de financiamento: Adriana Teixeira foi bolsista da Coordenação de Aperfeiçoamento de Pessoal de Nível Superior (Capes) no mestrado.

Considerações éticas: não há.

Agradecimentos/Contribuições adicionais: não há.

Histórico do artigo: submetido: 15 dez. 2019 | aceito: 12 mar. 2019 | publicado: 31 mar. 2020.

Apresentação anterior: não houve.

Licença CC BY-NC atribuição não comercial. Com essa licença é permitido acessar, baixar (download), copiar, imprimir, compartilhar, reutilizar e distribuir os artigos, desde que para uso não comercial e com a citação da fonte, conferindo os devidos créditos de autoria e menção à Reciis. Nesses casos, nenhuma permissão é necessária por parte dos autores ou dos editores. 


\section{Introdução}

Pouco mais de um século depois da gripe espanhola, a maior pandemia da história recente, os números da imunização da população no Brasil contra doenças contagiosas nunca estiveram tão baixos, em comparação com a última década, segundo estatísticas do Ministério da Saúde. A vacina contra a poliomielite, por exemplo, que alcançou 96,76\% da população em 2014, e 98,29\% em 2015, chegou a apenas 84,2\% em 2016. A imunização contra a hepatite tipo A, que atingiu 97,07\% da população em 2015, não ultrapassou os $71,57 \%$ em $2016^{1}$. E por que as pessoas têm se afastado das vacinas? Uma das causas da preocupante queda desses índices, segundo as autoridades sanitárias do país e internacionais, é a circulação massiva de fake news por meio das redes digitais. Cem anos após a morte de mais de 50 milhões de pessoas, entre 1918 e 1920, pelo imbatível vírus Influenza, multiplicam-se os discursos contra os métodos de imunização para doenças altamente contagiosas. Eles compõem posts, áudios e vídeos que se espalham por redes digitais e aplicativos de trocas de mensagens e disputam a atenção dos interlocutores com as vozes da ciência e do Estado, que reverberam a defesa da proteção do corpo contra todos os tipos de vírus. Boa parte dessas falsas notícias é produzida e despejada nas redes digitais pelos movimentos antivacinação, cuja atuação tem motivações políticas, ideológicas e religiosas, entre outras.

Na maioria das vezes, as fake news que se colocam contra os métodos de imunização validam a percepção enganosa de parte da população de que a vacina é dispensável porque as doenças (aparentemente) desapareceram da face da Terra. E colocam o ser humano no centro da decisão pela adoção ou repulsa à vacinação, isentando o indivíduo da responsabilidade coletiva pela saúde do corpo social. Geralmente, tais notícias falsificadas desvalorizam o conhecimento científico e colocam à prova os avanços da atividade acadêmica em direção à preservação da vida. As notícias falsas ganham ares de verdade na medida em que se alimentam (e causam o incentivo) da desconfiança da população na medicina convencional e nas instituições da saúde mantidas pelo Estado.

Entre os alvos recentes das fake news, no país, está a campanha de vacinação contra a febre amarela, que servirá de contexto pelos autores deste artigo para fazer a leitura da ação e da participação das fake news no processo de despotencialização dos programas de imunização. A campanha de âmbito federal foi uma reação ao surto da doença em fins de 2016, com os primeiros casos registrados e mortes no estado de Minas Gerais.

O diagnóstico da ação dessa praga digital ainda se busca, mas os efeitos já começam a ser mensurados. Executivos da Organização Mundial da Saúde (OMS), agência internacional especializada no assunto e subordinada à Organização das Nações Unidas (ONU), reconhecem que as fake news já representam, sim, uma das causas da baixa taxa de imunização contra doenças, principalmente nos países subdesenvolvidos. Em junho de 2018, a epidemiologista Laurence Cibrelus, da OMS, afirmou, em entrevista coletiva, que as notícias falsas tiveram forte influência, recentemente, na baixa cobertura vacinal contra a febre amarela no Brasil. Segundo ela, houve muita "desinformação de que a vacina inteira era perigosa e as doses fracionadas eram fracas, e o país enfrentou muitas dificuldades para, rapidamente, reverter essas informações". Em 30 de julho do ano passado, outra importante instituição da área, a Organização Pan-Americana da Saúde (Opas) alertou para a forte interferência das fake news nas taxas de imunização nas Américas, nos últimos anos, especialmente contra a disseminação do vírus do sarampo ${ }^{3}$. De onde vem a preocupação manifestada pela Opas? No Brasil, por exemplo, o índice de cobertura da vacina tríplice viral (sarampo, caxumba e rubéola) caiu de 100\%, mantido até 2004, para 85\%, em 2017, segundo dados do Ministério da Saúde. A taxa do número de crianças vacinadas contra o sarampo em Roraima e no Amazonas passou de 96\%, em 2015, para $84 \%$, em 2017, abrindo caminho para a volta da doença, segundo dados divulgados pelo Ministério da Saúde em junho de 2018. O vírus do sarampo havia sido eliminado do Brasil em 2016. De fevereiro a 23 de julho de 2017, deixou 822 pessoas doentes - foram 272 casos em Roraima, 519 no Amazonas, 14 no Rio 
de Janeiro, 13 no Rio Grande do Sul, 2 no Pará, 1 em São Paulo e 1 em Rondônia - e causou cinco mortes. Outros nove imunizantes indicados para o primeiro ano de vida, que protegem de 17 doenças causadas por vírus e bactérias, também tiveram a aplicação reduzida entre 2016 e 2017. Apenas a vacina BCG, para a produção de defesas contra bactérias que causam formas graves de tuberculose e é aplicada em dose única nas maternidades, atingiu o nível de 90\% de imunização recomendado pela OMS, afirma a pasta da Saúde4.

A Opas, em conjunto com a Organização Mundial da Saúde (OMS), chamou a atenção das Américas, em outubro de 2018, para a ampliação da cobertura da vacina contra a poliomielite - embora não haja o registro do poliovírus na região há 27 anos. O problema é que os países americanos não têm cumprido a meta de cobertura de vacinação de $95 \%$ da população infantil - e a volta da doença pode desencadear o surgimento de cerca de 200 mil casos por ano no mundo, estima a Opas5. Em 2016, a meta de vacinação contra a poliomielite no Brasil não foi cumprida, afirma o Ministério da Saúde: foram imunizados $86 \%$ da população - trata-se da pior taxa de vacinação nos últimos 12 anos. Em 2017, 23\% dos quase três milhões de crianças até um ano de idade não receberam a vacina, segundo o Ministério da Saúde ${ }^{1,6}$. Diante desses números, é importante afirmar que as fake news e seus aliados, os movimentos antivacina (cujas narrativas privilegiam as falsas notícias), não são os únicos responsáveis pelos índices de vacinação. Nesse contexto, têm influência também os investimentos feitos pelo governo federal em políticas na área da saúde e no planejamento de comunicação das campanhas de vacinação, principalmente, nas áreas de alto risco. No Brasil, o Programa Nacional de Imunização (PNI) é referência mundial por ter sido o pioneiro na incorporação de diversas vacinas no calendário do Sistema Único de Saúde (SUS).

Mas o risco de epidemias e a volta de doenças erradicadas não estão apenas do lado de cá do Atlântico e abaixo da linha do Equador. Em 20 agosto de 2018, a Organização Mundial da Saúde divulgou alerta internacional sobre o 'preocupante' aumento de casos de sarampo na Europa. No primeiro semestre, foram registrados 41 mil casos da doença nos 53 países que formam a região - no mesmo período do ano passado foram relatados 23.927 casos, segundo a organização. Entre 2016 e 2017, 35 pacientes morreram vítimas de sarampo. Surto com mais de 4 mil casos foi registrado na Itália, em 2017. Em abril do ano passado, nos Estados Unidos, cerca de 200 pessoas ficaram em observação, depois de 12 casos de sarampo - todos em crianças (menores de 6 anos) não imunizadas. O movimento antivacina, segundo a OMS, é, em parte, um dos responsáveis pelo problema. Com o surto da doença, em 2017, o então primeiro-ministro italiano Paolo Gentiloni, em entrevista coletiva, afirmou que a queda na cobertura vacinal do país para o vírus do sarampo, que passou de 90\% em 2011 para menos de 80\% em 2015, se deve, em parte, à propagação de "teorias anticientíficas"”.

A Itália foi um dos países onde ganhou grande repercussão o estudo do médico e pesquisador britânico Andrew Wakefield, publicado na revista médica britânica Lancet, em $1999^{8}$, que ligava a vacina tríplice (sarampo, caxumba e rubéola) ao desenvolvimento do autismo em crianças. A pesquisa foi realizada com 12 crianças, e, até 2015, nenhum outro estudo havia conseguido chegar às mesmas conclusões que o trabalho de Wakefield. As autoridades norte-americanas calculam que cerca de 100 mil crianças não foram vacinadas naquele ano. $\mathrm{O}$ artigo foi retirado das publicações científicas em 2010, e o pesquisador proibido de exercer a profissão. Mesmo assim, em 2012, um tribunal em Rimini, na Itália, determinou que a família de um garoto com autismo recebesse indenização sob o argumento de que a doença fora resultado da aplicação da vacina9 ${ }^{9}$ Três anos depois, a decisão foi revogada. Em 2004, a imprensa internacional tinha divulgado documentos que provavam que Wakefield havia entrado com pedido de patente para uma vacina contra o sarampo que concorreria com a fórmula da tríplice viral MMR que seu estudo contestava ${ }^{10}$. Novos estudos foram lançados sobre o tema, e, em abril de 2015, pesquisa norte-americana, publicada na Journal of the American Medical Association (JAMA) ${ }^{11}$, desta vez realizada com 95 mil crianças, revelava que não há relação entre a vacina tríplice e o autismo. Outra pesquisa realizada na Dinamarca com mais de 600 mil crianças, publicada em abril de 2019, na revista científica Annals of Internal Medicine ${ }^{12}$, do American 
College Physicians, também desvincula a vacina tríplice viral do autismo. Pesquisadores do Statens Serum Institut, um dos maiores institutos de pesquisa no setor da saúde daquele país e localizado em Copenhague, acompanhou o desenvolvimento de crianças nascidas entre 1999 e 2010, desde o momento em que foram vacinadas até agosto de 2013. Apesar das constatações científicas sobre a eficiência das vacinas e o baixo risco de efeitos colaterais provocados por elas, e da divulgação dessas descobertas por revistas científicas e por meios de comunicação de massa, a falsa afirmação de que elas causam autismo nas crianças ainda é maciçamente utilizada pelos movimentos antivacina em seus posts, áudios e vídeos que circulam 'eternamente' pelas redes digitais e sites.

\section{Disputa da verdade}

Mas o empenho da ciência para derrubar as falsas afirmações, que se cristalizam no tempo, não tem se mostrado capaz de cumprir o intuito e de reduzir o poder das fake news que atuam contra os programas de imunização no mundo inteiro. O Estado e a imprensa - outros dois importantes enunciadores da verdade - também estão perdendo a disputa. O que tem levado, então, as fake news para esse lugar de destaque na enunciação da verdade? A impotência dos outros enunciadores? Os resultados considerados contraditórios das pesquisas científicas, ao longo dos anos, parecem ter reduzido a voz da ciência no debate público. Pesquisas que comprovam a eficiência das vacinas não conseguem desfazer o que foi dito pela mesma ciência há alguns anos. E os meios de comunicação de massa já não têm mais a audiência que possuíam no passado para fazer reverberar as descobertas da ciência. E o Estado? Sem a força da mídia e o embasamento de uma ciência que possa ser acreditada, o governo também parece ter ficado sem forças para enfrentar as notícias falsas. De outro lado, surgem grupos profissionais cada vez mais detentores da lógica de funcionamento das redes digitais, preparados para a produção cada vez mais eficaz de falsas notícias.

Podemos afirmar que as fake news assumiram o controle dos discursos que funcionam como verdadeiros neste embate com a ciência, o Estado e a imprensa? Elas passam a participar da construção de um novo regime de verdade que, segundo o filósofo Michel Foucault ${ }^{13}$, representa o conjunto de regras segundo as quais se distingue o verdadeiro do falso e se atribui aos verdadeiros efeitos específicos do poder. Esse conjunto de regras são procedimentos regulados para a produção, a lei, a repartição, a circulação e o funcionamento de enunciados, e está ligado a sistemas de poder, que o produzem e apoiam: "Em nossas sociedades, a economia política da verdade tem cinco características historicamente importantes: a verdade é centrada na forma do discurso científico e nas instituições que o produzem; está submetida a uma constante incitação econômica e política (necessidade de verdade tanto para a produção econômica, quanto para o poder político); é objeto, de várias formas, de uma imensa difusão e de um imenso consumo (circula nos aparelhos de educação ou de informação, cuja extensão no corpo social é relativamente grande, não obstante algumas limitações rigorosas), é produzida e transmitida sob controle, não exclusivo, mas dominante, de alguns aparelhos políticos ou econômicos (universidade, Exército, escritura, meios de comunicação); enfim, é objeto de debate político e confronto social (as lutas ideológicas)"13.

As fake news determinam condutas, ao influenciarem eleições políticas, favorecerem resultado de plebiscitos e participarem na redução nos índices de vacinação. Elas começam a tomar a dianteira em relação aos demais aparelhos enunciadores da verdade, como o Estado e a imprensa, porque buscam inspiração nas crenças e dogmas da época, ou seja, elas pronunciam a verdade em que se quer acreditar - e renunciam a toda verdade que exige a vontade de crer. O pesquisador Igor Sacramento, do Laboratório de Comunicação e Saúde, do Instituto de Comunicação e Informação Científica e Tecnológica em Saúde (Icict), da Fundação Oswaldo Cruz (Fiocruz), que estuda as fake news na área da saúde, afirma, em editorial da Reciis (Revista Eletrônica de Comunicação, Informação e Inovação em Saúde), da Fiocruz, que a sociedade passa de um regime de verdade baseado na confiança nas instituições para outro regulado pelas crenças, pela intimidade, pela experiência pessoal ${ }^{14}$. A dogmatização, escreve Sacramento, é vista, por exemplo, na 
difamação sistemática, nas redes, da vereadora Marielle Franco, desde seu assassinato em 14 de março de 2018. Nos posts, ela encarna o que o pensamento conservador brasileiro rejeita: feminista, lésbica, negra, oriunda da Favela da Maré, socióloga, ativista dos direitos humanos, de esquerda. Essa é uma verdade baseada nas crenças - a verdade em que se quer acreditar. As fake news buscam na performance da noticiabilidade os recursos para construir tal verdade. Elas apresentam a notícia performaticamente, combinando enunciados da época, crenças e desafiando os enunciadores oficiais. E convencem porque supõem o desmonte da necessidade da crítica. Como afirma Hannah Arendt: "O resultado de uma substituição total e consistente da verdade factual por mentiras não é que a mentira será agora aceita como verdade e que a verdade será difamada como uma mentira, mas que o próprio senso pelo qual nos orientamos no mundo real -e a categoria de verdade como oposta à de falsidade está entre os recursos mentais que nos orientam - está sendo destruído"15.

Neste ponto da reflexão sobre a enunciação da verdade - produzida e transmitida sob controle, não exclusivo, mas dominante, de alguns aparelhos econômicos, segundo Foucault - torna-se imprescindível a leitura do ambiente de performance em que se encontram essas fake news: as redes digitais, como Facebook, Twitter, Instagram e WhatsApp. Na comunicação em rede e por meio de aparelhos digitais, a mediação da informação exercida até então pelos tradicionais veículos de comunicação e, consequentemente, o desmonte da ponte que parecia tão sólida e confiante na distinção entre emissor e receptor, já não afetam, como antigamente, o sujeito que anseia por participar da cultura. Testemunhamos, então, o crescimento da influência das redes digitais no debate público em detrimento da participação dos veículos de imprensa no Brasil e em outras partes do mundo. No Sudeste brasileiro, por exemplo, desde 2011, 331 veículos (jornais e revistas impressos e versões online) encerraram suas atividades por dificuldades financeiras, segundo mapeamento feito pelo Atlas da Notícia ${ }^{16}$. A comunicação das mediações é, por definição, segundo Lucrécia D’Aléssio Ferrara, anticomunicativa porque, centralizada nos objetivos do emissor, desconsidera a atmosfera cultural que define o receptor, que não pode ser considerado massa uniforme e passiva ${ }^{17}$. As fake news, então, levam em consideração a disposição à comunicação do sujeito conectado: “O público que ganhou poder com as novas tecnologias, e que vem ocupando um espaço entre os velhos e novos meios de comunicação, está exigindo o direito de participar intimamente da cultura"18. A mediação dos meios de comunicação, como conhecemos, perdeu lugar para a eloquência da rede digital. A combinação de notícias falsas que se alastram rapidamente pelas redes na área da saúde, questionando os efeitos e a validade das vacinas, e ganha status de verdade na multiplicação dos compartilhamentos, obedece à dinâmica desse novo modo de se comunicar, em que prevalecem a interatividade e ambivalência: "Como designer de significados, o receptor abandona o nicho que lhe havia sido reservado pela mediação programada pelos meios técnicos, abandona os veículos qualificados pela eficiência do modo como se desempenha, para aderir aos estímulos interativos de comunicar que o faz desenhar a comunicação que convém ao seu contexto e produzir não a eficiência extensiva da comunicação instrumental, mas a redescobri-la no instante em que configura a mediação como um espaço entre: uma espacialidade midiática que se distingue da natureza física do espaço, exatamente pela natureza física de sentido fluído, indeterminado, ambivalente, interativo”17.

\section{Metodologia}

É nesse ambiente da interatividade que as fake news ganham força e se expandem no mundo altamente conectado. Elas se fazem presentes em todas as redes digitais e contam com a disposição do indivíduo ao compartilhamento das informações, sejam elas falsas ou verdadeiras. Já que cada rede digital tem características distintas de funcionamento, os autores deste artigo estabeleceram cinco critérios para a seleção dos posts que circulam falsa informação contra a vacinação da febre amarela. São eles: 
1) Estrutura do texto que dá suporte às fake news:

Os posts foram compartilhados em rede digital no formato de texto, em língua portuguesa. A opção pelos posts em língua portuguesa justifica-se pela presença da doença e da realização da campanha de vacinação especificamente no Brasil, país que fala o idioma. Não houve restrição quanto ao número de palavras que compõem cada um dos textos, porque o objetivo é concentrar a análise na produção de sentido das falsas informações que se apresentam como verdade. A presença de imagens nos posts (fotos, ilustrações, reproduções de figuras, desenhos ou logotipos, entre outros) não foi levada em consideração no processo de seleção dos textos, porque este artigo propõe a leitura específica da narrativa escrita.

2) Especificidade do conteúdo das fake news:

Todos os posts selecionados pelos autores têm as palavras 'febre amarela' e/ou 'vacina', porque a leitura a que se propõe este artigo concentra-se nas fakes news que contestam a validade da imunização contra a doença ou fizeram circular falsas informações sobre a febre amarela, prejudicando, assim, a eficiência da campanha de vacinação lançada no país.

3) Meio de comunicação e circulação das fake news:

Esses textos circularam, principalmente, no aplicativo privado de distribuição de mensagens WhatsApp, a segunda rede digital mais usada pelos brasileiros, com 120 milhões de usuários, depois do Facebook, com 127 milhões, segundo pesquisa realizada pela agência digital internacional We are Social, divulgada pelo site Rock Content ${ }^{19}$. O WhatsApp é apontado por especialistas no país como o maior multiplicador de fake news, em ambiente digital privado, com alto índice de interatividade. Nas eleições brasileiras, em 2018, foi largamente utilizado para a disseminação de fake news em campanhas políticas, chamando a atenção de instituições internacionais, como a Organização dos Estados Americanos (OEA), que faz o acompanhamento dos processos eleitorais nas Américas.

4) Período de circulação das fake news:

As mensagens selecionadas pelos autores começaram a circular nas redes digitais e aplicativos de trocas de mensagens, segundo agências checadoras de notícias, entre os anos de 2016 e 2017, período de uma grande onda da febre amarela no país, quando os alertas para a necessidade da vacinação, feitos por instituições da saúde e veículos de comunicação em massa, foram mais frequentes devido aos primeiros casos da doença naquele período e de mortes registrados em hospitais e unidades de atendimento de emergência no país. É importante ressaltar que algumas dessas mensagens permanecem presentes na rede. Os posts que serão apresentados a seguir foram coletados pelos autores em seus próprios aplicativos do WhatsApp, durante todo o ano de 2018. As mensagens foram selecionadas em grupos de amigos e de família dos quais os autores participam. Parte dos posts que constam deste artigo também chegaram no WhatsApp dos autores mediante solicitação dos mesmos feita para comunidades diversas presentes nas redes digitais, especialmente aquelas em que participam profissionais da área da saúde.

5) Fake news submetidas a serviço de checagem de fatos:

Os textos apresentados neste artigo foram submetidos à checagem de informação feita por agências, instituições ligadas à imprensa ou veículos de comunicação especializados na verificação de fatos. São eles: o site do médico Drauzio Varella ${ }^{20}$, a agência Lupa ${ }^{21}$, os sites Aos Fatos ${ }^{22}$, Fato ou Fake ${ }^{23}$, Boatos.org ${ }^{24}$, E-Farsas ${ }^{25}$, É ou Não É É ${ }^{26}$ do portal de notícias G1, e o serviço Saúde sem Fake News, do Ministério da Saúde $^{27}$. A sessão Febre Amarela: Perguntas e Respostas, do site da Fiocruz ${ }^{28}$, também foi consultada no processo de seleção dos posts, porque o serviço ofertado pela instituição esclarece dúvidas relacionadas às afirmações espalhadas pelas fake news. 
Depois de selecionadas a partir desses cinco critérios, as fake news foram categorizadas, com a indicação do principal recurso narrativo que opera na produção de sentido e convoca o leitor a compartilhar o post e se colocar contra a vacinação - influenciando, assim, a tomada de decisão e, consequentemente, a atitude do indivíduo. Nessa categorização, indicamos o que confere credibilidade às fake news, ou seja, qual o ponto em que essas notícias fabricadas apelam às crenças e à subjetividade daquele que entra em relação com elas. Também procuramos demonstrar, em alguns posts, quais os (falsos) argumentos utilizados pelas fake news na construção do texto que desclassifica a vacinação como um meio de preservação da saúde. Assim como a campanha de vacinação contra a febre amarela, as fake news também se colocam em defesa da vida, mas com a indicação de supostos efeitos colaterais.

Entende-se, portanto, que a motivação da sociedade para proteger a saúde - argumento presente no discurso de enunciadores da verdade, como ciência, mídia e Estado - é, inversamente, utilizada pelas fake news para convencer o indivíduo a negar a vacinação como meio de manutenção desta mesma saúde coletiva e individual. Mas, ao mesmo tempo que as fake news invadem as redes digitais em defesa da vida, elas desprotegem o corpo de doenças e o colocam sob o risco de morte.

\section{Combinação de alimentos substitui a vacina contra a febre amarela?}

Segundo estudo divulgado pelo Ministério da Saúde, em agosto de 2019, os supostos efeitos colaterais das vacinas e a combinação de alimentos para combater doenças estão entre os principais temas presentes na narrativa das fake news que operam na comunicação na área da saúde. O levantamento aponta que as vacinas são relacionadas pelas fake news a todo tipo de males à saúde, como o autismo em crianças e o adoecimento do fígado nos adultos; e os alimentos são indicados como substitutos dos medicamentos para a imunização ou cura de doenças graves, como o câncer. O órgão do Estado chegou a essa conclusão após mensurar os resultados de seu serviço de checagem de notícias falsas, o Saúde Sem Fake News, iniciado em agosto de 2018, e que fez a análise de 12.200 posts que circularam em todas as redes digitais no Brasil ${ }^{29}$.

As fake news que indicam simples receitas caseiras para a substituição das vacinas estão sempre presentes nas redes digitais - porque são resultado da interatividade do indivíduo nas redes. Esse compartilhamento de mensagens parece não ter fim porque elas se impõem como verdadeiras. E por quê? Primeiramente, elas aproveitam a ampliação do discurso que defende a adoção de alimentos naturais em vez dos processados e industrializados - argumento fortalecido pela mídia, que propaga os prejuízos à saúde causados por conservantes e outros elementos químicos na preparação de refeições oferecidas no mercado. Assistimos ao crescimento do número de processos judiciais contra empresas fabricantes de produtos químicos para a produção de alimentos, por exemplo, movidos por consumidores que adoeceram profundamente depois da ingestão sistemática de determinados produtos. Há, então, um discurso presente na sociedade de que a participação da indústria química na produção de alimentos ou de medicamentos causa mal à saúde. Tal afirmação abriu espaço para outro discurso se propagar: o emprego de produtos naturais contra doenças pressupõe uma vida saudável e a manutenção de um corpo livre da química dos medicamentos e das vacinas, alvos de críticas por seus supostos efeitos letais. Neste ponto, outra evidência e constatação importante: a desqualificação total da ciência pelas fake news - e aceita pelo indivíduo que acolhe a informação sem base científica. Resultados de anos de pesquisa e investimentos financeiros, os medicamentos podem ser simplesmente, segundo as fake news, substituídos por produtos naturais. Elas ganham credibilidade porque apelam às crenças da civilização de que os produtos naturais são inofensivos à saúde e têm poder de cura. E de onde vem essa crença? Da mesma indústria de alimentos, mas a que prega a vida natural. Somos afetados, repetidamente, por discursos da imprensa e da propaganda que nos motiva a adotarmos um 'estilo de vida saudável', livre da química da indústria. 
Quem não ouviu um amigo ou parente falar dos poderes mágicos da própolis para espantar o mosquito da febre amarela ou da dengue? Segundo a receita que circula até hoje nas redes, basta ingerir com água algumas gotinhas do substrato das abelhas, no período da manhã, e outras tantas no período da tarde, para considerar-se a salvo do mosquito transmissor da doença. Os textos afirmam que determinadas substâncias contidas na própolis, depois de assimiladas pelo organismo humano, funcionam como um tipo de repelente, afastando para muito longe os mosquitos da dengue, zika e febre amarela. A Fiocruz, em sua sessão Febre Amarela: Perguntas e Respostas, faz alguns esclarecimentos sobre a falsa informação: "Não existem estudos científicos que indiquem que a própolis seja um imunizante contra a febre amarela. São rumores sem nenhum embasamento científico"30. O site Boatos.org chama a atenção para a frequente 'reciclagem' das fake news: "A história que aponta que a própolis é um repelente já era falsa em 2008, quando falava só da dengue, era falsa em 2016, quando falava da zika, e é falsa agora, quando fala da febre amarela. Cuidado com as receitas milagrosas sem qualquer comprovação científica"’31. A seguir a mensagem que circulou no WhatsApp:

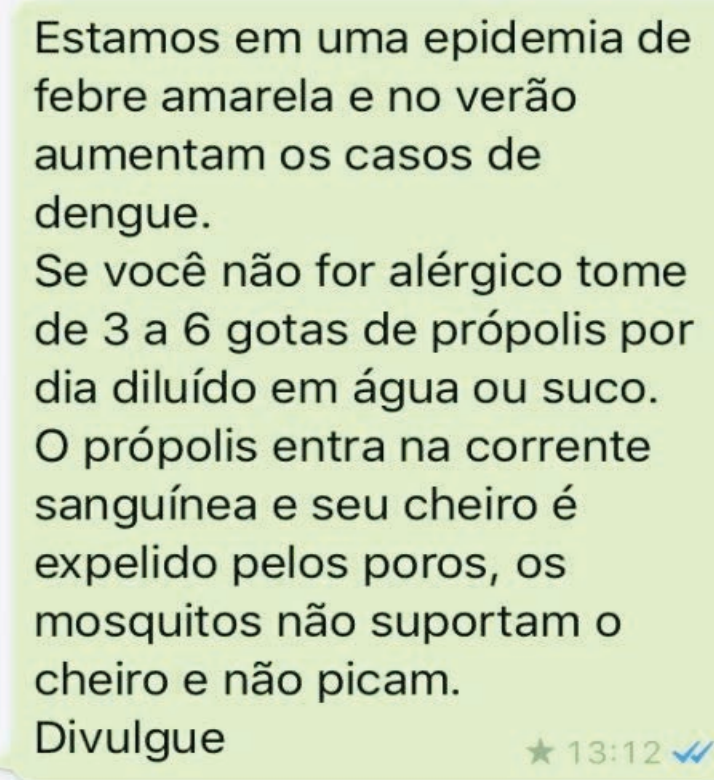

Figura 1 - Repelente natural: própolis vira produto contra febre amarela e dengue, sem qualquer base científica Fonte: Dados da pesquisa (2019).

O post da Figura 2 apresenta semelhante construção da narrativa do texto anterior: propõe o emprego dos benefícios dos produtos da natureza contra os efeitos colaterais da indústria farmacêutica. O texto contém uma receita muito simples e composta apenas por ingredientes da natureza para atuar como imunizante à febre amarela. E ainda especifica a tal receita como um tipo de cura em 12 dias para aqueles que estiverem doentes. 


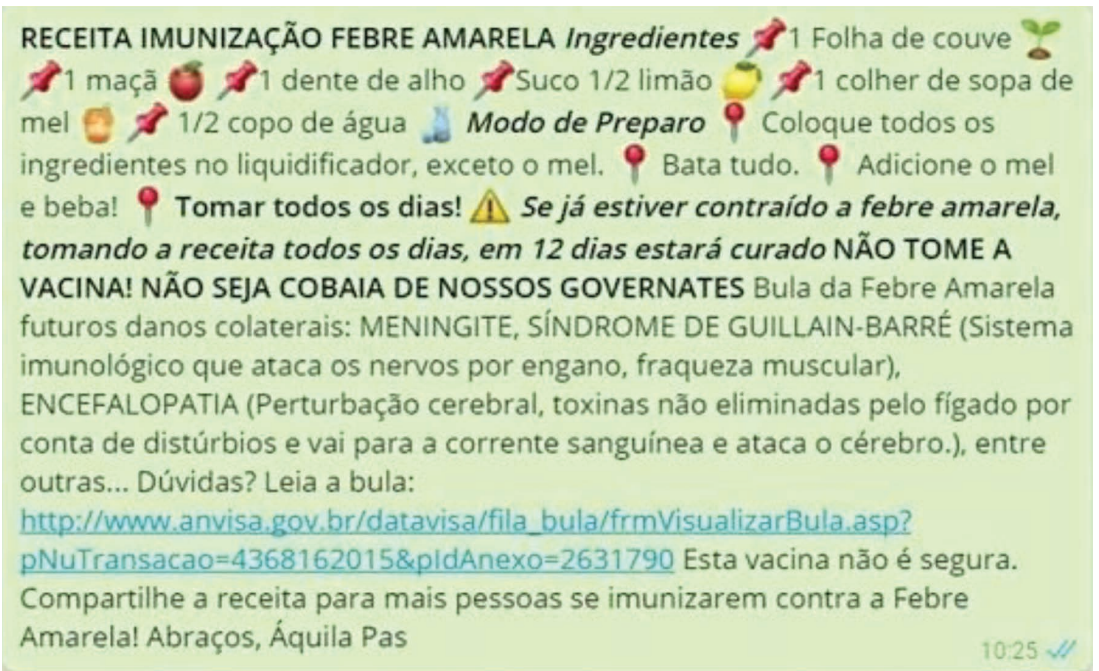

Figura 2 - Receita da saúde: couve, alho, limão e maçã misturados para substituir o imunizante da indústria farmacêutica Fonte: Dados da pesquisa (2019).

Como afirma o médico infectologista e pesquisador da Fiocruz André Siqueira, membro da Sociedade Brasileira de Medicina Tropical (SBMT), para o site de checagem de notícias falsas do G1, "a mensagem é uma besteira. Não tem nenhuma verdade no que a pessoa que escreveu diz. Em primeiro lugar, a vacina é uma vacina efetiva e segura. Os eventos adversos que acontecem são extremamente raros. A vacina é a melhor forma de combater a doença. Outras formas de combater são as que diminuem o contato do homem com o mosquito, ou seja, repelente, mosquiteiro, que são proteções adicionais. A receita que é colocada lá não tem nenhum efeito, nenhuma validade para febre amarela, nem como imunização, nada" ${ }^{2}$.

\section{Vacina contra a febre amarela tem graves efeitos colaterais?}

No mesmo post, são indicados ainda os supostos efeitos colaterais da vacina contra a febre amarela: meningite, Síndrome de Guillain-Barré e encefalopatia. Tratam-se de informações geralmente muito exploradas pelos movimentos antivacina no mundo inteiro, especialmente nos Estados Unidos, Europa e, recentemente, com grande presença, no Brasil. A Síndrome de Guillain-Barré foi associada às vacinas, em 1976, quando uma americana apresentou os sintomas da doença autoimune, após receber um antídoto contra um tipo de gripe, relata a imprensa da época. A americana teve paralisia nas pernas e percorreu uma série de programas de entrevistas considerados sensacionalistas, nos Estados Unidos ${ }^{33}$. Embora não haja estudos científicos que comprovem a relação da doença, que provoca danos neurológicos, com vacinas, a (polêmica) informação está sempre presente nas fake news e é apresentada como verdade absoluta. No mesmo texto, o link que deveria ser da Anvisa, apontado como fonte da descrição dos letais efeitos colaterais das vacinas, não leva a qualquer tipo de informação sobre o assunto. A indicação de fontes de informação, com a referência para links de acesso a sites oficiais, por exemplo, é utilizada pelos divulgadores de fake news como recurso para que a mensagem pareça realmente verdadeira e passível de comprovação. Ou seja, as fake news incluem em seus textos a indicação de fontes institucionais e/ou oficiais do tema abordado por elas, mas com a inversão dos argumentos. Então, se as instituições são empregadas pelas notícias fabricadas como índice de credibilidade, porque elas não conseguem combater as fake news e os movimentos antivacina?

No Brasil, ainda não há levantamento específico sobre a atuação dos grupos antivacinas formalmente constituídos, como, por exemplo, nos Estados Unidos. Mas, pelo crescimento da criação de comunidades nas redes digitais e da circulação e compartilhamento de posts, há percepção da ampliação do número de adeptos. No Facebook foram formadas, nos últimos quatro anos, segundo levantamento feito pelos autores 
deste artigo, as comunidades O Lado Obscuro das Vacinas, Associação e Parentes das Pessoas que Tiveram Reação Pós- Vacina da Febre Amarela, Antivacinação: Ciência, Evidência e Debate e Vacinas e Religião, com mais de mil integrantes por grupo. Pesquisa realizada pela Sociedade Brasileira de Imunização, em parceria com o Instituto Brasileiro de Opinião e Estatística (Ibope), divulgada em novembro de 2019, destaca a atuação de outros dois movimentos antivacinas: Cruzada pela Liberdade e Contra Nova Ordem Mundial ${ }^{34}$. Esses grupos afirmam que as vacinas alteram o DNA, debilitam o organismo, causam alergias, autismo e pedra nos rins, entre outros males, em crianças e adultos. São argumentações sem qualquer comprovação científica, mas com depoimentos, em texto e vídeo, de supostas mães sobre filhos que ficaram gravemente doentes depois de receberem vacinas. Alguns posts incluem fotos de crianças e afirmam que as imagens foram produzidas antes e depois da imunização.

Os grupos antivacinas, e suas declarações em formato de texto, áudio ou vídeo, representam importantes fontes de (des)informação para a elaboração das fake news que circulam nas redes. Neste ponto do artigo, usamos a palavra (des)informação para designar o resultado da atuação desses movimentos porque entendemos que eles descontroem a informação a partir de interesses políticos, ideológicos e religiosos. No processo de coleta dos posts para a leitura a que se propõe este artigo, percebemos que boa parte das fake news que circulam temas da saúde pública busca seus argumentos em discursos construídos pelos movimentos antivacinas, que relacionam, principalmente, efeitos colaterais da imunização sem comprovação científica, além das chamadas 'teorias da conspiração'. Entre estes grupos antivacina que mantêm comunidades ativas no Facebook, um dos poucos que tinham site atualizado era o Pensa Brasil, com informações sobre política (de direita), religião e celebridades. Eram textos que copiavam exatamente a estrutura da narrativa jornalística: tendo título, subtítulo, fotos e legendas, com o objetivo de se apresentar totalmente crível - assim como os veículos de comunicação de massa. Novamente, as notícias fabricadas buscam referências em instituições entendidas como verdadeiras pela sociedade. Em uma das 'notícias', o Pensa Brasil relacionou a febre amarela com as bombas dos Estados Unidos contra Hiroshima e Nagasaki, no Japão, em 1945, ou seja, um tipo de conspiração para o extermínio da população. Esse site associava a vacina contra a febre amarela a um veneno mortal e que tem como objetivo a morte imediata de uma grande parcela da população ${ }^{35}$ :

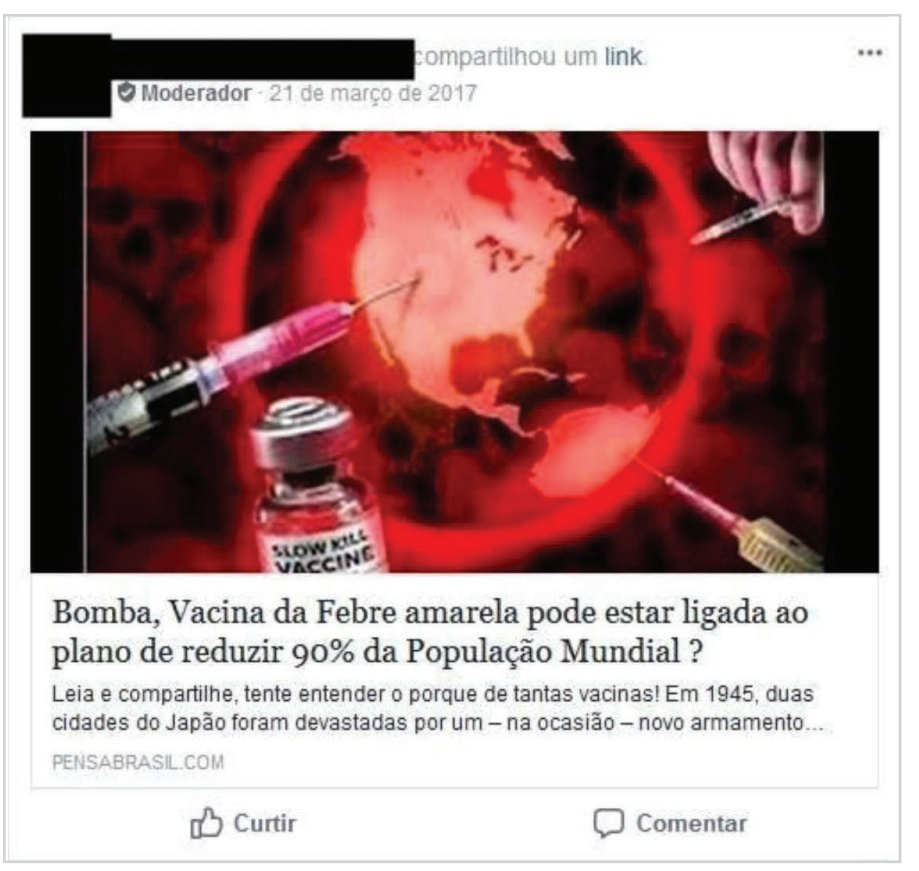

Figura 3 - Teoria da conspiração: Pensa Brasil, página de movimento antivacina no país, tem fake news com formato de notícia Fonte: Página PensaBrasil.com (2017). 


\section{A (simples) solução para a doença da febre amarela está na indicação (e eliminação) dos culpados?}

As fake news ainda se colocam como as primeiras vozes das redes digitais a apresentarem respostas às dúvidas ou angústias da sociedade. $\mathrm{E}$ apontam falsos culpados. No caso da febre amarela, uma das primeiras notícias falsas que começaram a invadir as redes digitais afirmava que a 'culpa da proliferação da doença era dos macacos'. Mais uma vez, as fake news não só enganaram os leitores, mas incentivaram condutas de uma população tomada pelo medo de contrair a doença. A notícia falsa de que os macacos transmitiam a febre amarela levou à morte de animais, principalmente no Rio de Janeiro, que registrava, na época, maior número de casos. Em 25 de janeiro de 2018, a Agência Brasil, agência pública de notícias, informou que 131 macacos haviam sido mortos em três semanas no estado, e que 69\% deles tinham sinais de envenenamento e espancamento, ou seja, foram assassinados pelas mãos do homem, segundo dados da Secretaria de Vigilância, Fiscalização Sanitária, e Controle de Zoonoses da Prefeitura da Cidade do Rio de Janeiro $^{36}$. Essas fake news relatam exatamente o oposto da informação, porque os macacos, diferentemente do que afirmam as notícias falsas, ajudam a população a encontrar os focos da febre amarela, enfatizam especialistas consultados pelas agências checadoras de notícias falsas.

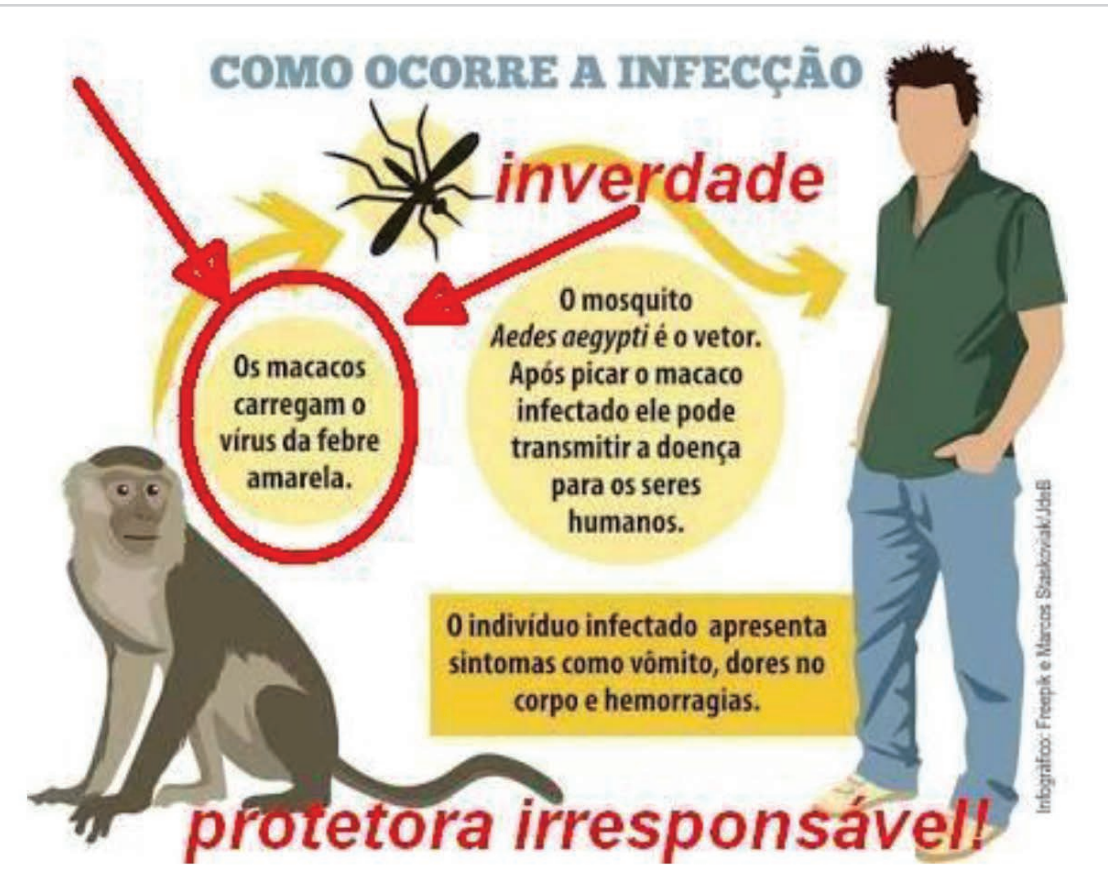

Figura 4 - Contaminação da notícia: os macacos foram transformados nos culpados pela proliferação da doença Fonte: Dados da pesquisa (2018)i.

\section{A voz (in)competente ataca a vacina contra a febre amarela}

As fake news na área da saúde usam também a voz de médicos, enfermeiros e de funcionários de hospitais para convencer e enganar seus leitores. Trata-se de notícias falsas com depoimentos e testemunhos, num discurso na primeira pessoa. Nesse tipo de narrativa, a experiência do profissional legitima o conhecimento da verdade. É a voz da competência - muitas vezes inquestionável pela sociedade. É a mesma usada pela imprensa quando se coloca a defender uma posição. As notícias fabricadas empregam recurso semelhante porque o especialista é reconhecido pela sociedade como o detentor da verdade. Com o uso da voz competente, as fake news buscam o convencimento e atuam para influenciar o comportamento do leitor. A mensagem apresentada na Figura 5, que também circulou pelo WhatsApp, força o leitor a acreditar que o

i Imagem obtida pelos autores em rede social. 
texto representa a fala de uma enfermeira, 'com mais de 20 anos de experiência', e que questiona a gravidade da doença. Para lembrar, o surto da febre amarela, que começou em Minas Gerais, entre os anos de 2016 e 2017, deixou 261 Jô mortos, segundo o Ministério da Saúde ${ }^{37}$. O texto contesta as informações divulgadas pela imprensa sobre infectados e mortos, faz afirmações equivocadas sobre a forma como o corpo humano se recupera da doença e menciona o mercúrio na composição da vacina. "Não, a vacina contra a febre amarela não possui mercúrio em sua formulação, e nenhum outro metal. Conforme descrito na bula, a vacina contra a febre amarela produzida por Bio-Manguinhos/Fiocruz contém excipientes como a sacarose, glutamato de sódio, sorbitol, gelatina bovina hidrolisada, eritromicina e canamicina” ${ }^{38}$, publica a Fiocruz na sessão Febre Amarela: Perguntas e Respostas em seu site. No post que mostramos a seguir, observamos a reprodução de um estado psicológico muito presente na sociedade: a desconfiança. Além da ciência e do Estado, a imprensa também tem sido submetida ao questionamento sobre a veracidade das suas narrativas. As fake news, então, capturam essa expressão do corpo social e fazem coro com a sociedade - mais um recurso para tornar-se crível.

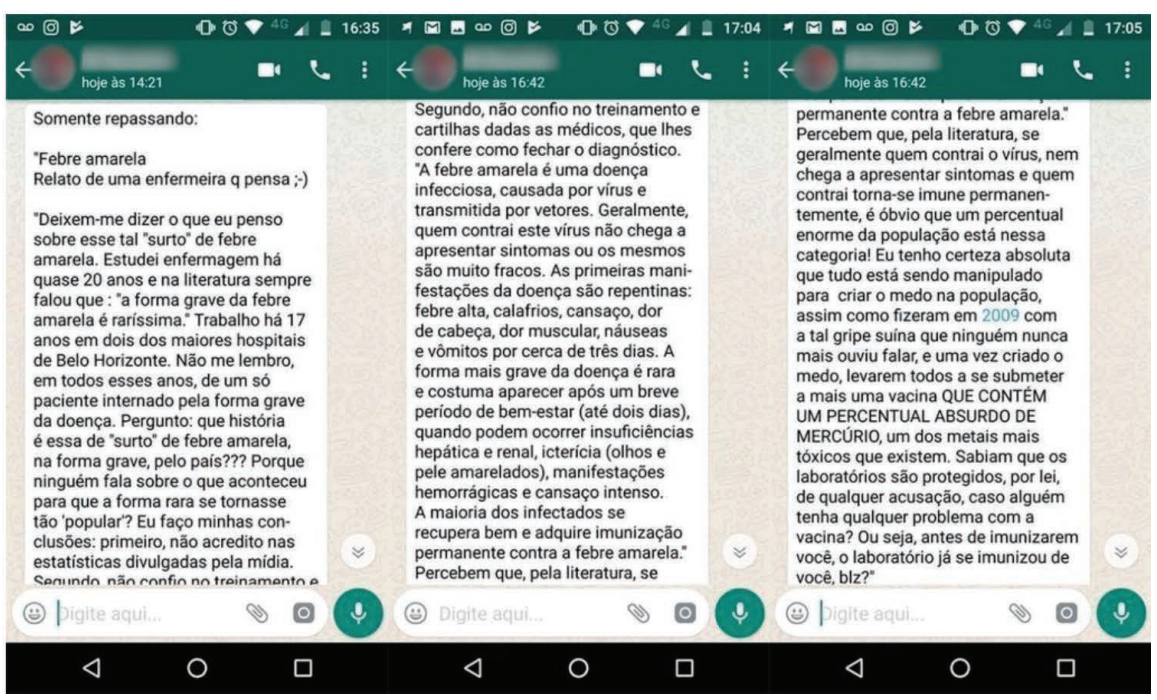

Figura 5 - Voz (in)competente: enfermeira com 20 anos de profissão questiona a gravidade da doença Fonte: Dados da pesquisa (2019).

\section{A saúde sob risco e o apelo ao pânico}

Nem sempre as notícias falsas na área da saúde constroem narrativas que induzem o interlocutor a se negar à vacinação. Algumas delas buscam provocar o pânico entre os receptores da mensagem para, igualmente, gerar algum descontrole da situação social e novamente colocar a vida sob risco. O texto abaixo também circulou em áudio no WhatsApp, em janeiro de 2018, quando os alertas sobre a doença foram mais frequentes. Nele, a narradora afirma estar no Hospital das Clínicas (na cidade de São Paulo). O áudio emite sons que sugerem um ambiente hospitalar, com vozes, alarmes de equipamentos médicos e campainha de telefones. Ela descreve as condições de supostos pacientes que sofrem uma série de sintomas físicos causados pela febre amarela, além de casos de mortes provocadas pela doença:

Bom dia, meus amores. Deixa eu falar uma coisa para vocês. Chegaram esta noite aqui no HC três casos de febre amarela confirmados. Um do Jaçanã, outro paciente do Horto Florestal e outro de Itaquaquecetuba. Então, entre esses três pacientes, um já está em estado grave entubado e os outros dois chegaram andando e conversando. Esses dois que chegaram andando e conversando já estão entubados, em estado gravíssimo, e com o fígado já quase explodindo. Porque essa doença febre amarela, ela fulmina o fígado, ela acaba com o fígado e é por isso que os pacientes morrem. Pacientes fortes, tá? Ninguém era magro. Pacientes fortes e jovens, de 30 e 32 anos. O primeiro caso que chegou aqui no HC foi uma 
paciente chamada Mariana, de 32 anos, e já chegou com hepatite fulminante e já chegou aguardando transplante de fígado, porque não tinha o que fazer. Ela não aguentou e morreu. Eu estava conversando agora com uma enfermeira da UTI, onde estão ficando esses pacientes da febre amarela, e ela falou que está dando dó, porque os pacientes são jovens, fortes e os médicos não estão sabendo o que fazer. De dez pacientes que ela está cuidando, só um sobreviveu. Então é preciso tomar a vacina. Procura algum posto de saúde e toma a vacina, porque é a única precaução. Não tem outro jeito. A febre amarela não tem cura (áudio do WhatsApp; 2018 jan.).

Essa notícia falsa tem uma tendência a provocar um movimento descontrolado da população aos postos de saúde em busca da imunização. O Boatos.org cita uma reportagem do jornal O Estado de S. Paulo, publicado em 19 de janeiro de 2018, na época em que o áudio e o texto viralizaram, para sugerir uma possível causa desse tipo de fake news: "A busca da vacina contra a febre amarela está fazendo muitas pessoas cruzarem a capital paulista e se deslocarem por até 30 quilômetros, justamente para áreas de risco de contaminação pelo vírus, como a zona norte da capital. A procura inclui até moradores de outras cidades, como Guarulhos"39. Na época, a Secretaria de Estado da Saúde alertou a população a não se deslocar às áreas de risco apenas em busca da vacina, reservada àqueles que frequentavam as regiões onde já havia casos da doença. Naquele mesmo período, o Hospital das Clínicas, segundo o Boatos.org, publicou em sua página no Facebook a seguinte informação, talvez prevendo um aumento da demanda da população pela vacinação: "O Centro de Imunização do HCFMUSP passará a exigir comprovante de viagem para áreas de risco de quem for receber a vacina contra febre amarela. Pacientes com condições especiais, com encaminhamento por escrito da rede básica de saúde, também poderão ser vacinados no local. Os demais deverão procurar os postos da rede básica de saúde"39.

Além de possivelmente ter contribuído para o deslocamento indevido da população em busca da vacina, para zonas de contaminação, o que poderia provocar uma proliferação da doença sem precedentes, o texto é inteiro construído com informações falsas. A Secretaria de Saúde estadual informou, em janeiro de 2018, que ao longo de 2017 foram registradas 21 mortes no estado de São Paulo - nas cidades de Américo Brasiliense (uma morte), Amparo (três), Atibaia (quatro), Batatais (uma), Itatiba (uma), Jarinu (uma), Mairiporã (cinco), Monte Alegre do Sul (uma) e Nazaré Paulista (uma) ${ }^{40}$. E absolutamente nenhuma na capital paulista, onde está o Hospital das Clínicas. Mais uma vez, as fake news que defendem a manutenção da saúde acabam colocando a vida em risco.

Apesar do trabalho dos órgãos de saúde no país e das agências checadoras de notícias falsas, as fake news avançam. Pesquisa da Sociedade Brasileira de Imunização, divulgada em novembro de 2019, mostra que sete em cada dez brasileiros acreditam em fake news sobre vacinas ${ }^{34}$. Dez afirmações falsas foram apresentadas aos entrevistados e mais de dois terços disseram que, pelo menos, uma delas era verdadeira. Os questionários foram aplicados pelo Ibope em duas mil pessoas. Quarenta e oito por cento dos entrevistados disseram que as redes digitais são suas fontes de informação. Mais de 80\% afirmaram nunca terem deixado de se imunizar ou vacinar seus filhos. Mas o restante afirmou que não adere à vacinação porque não acha a imunização necessária, tem medo de contrair a doença que estava tentando prevenir, tem receio dos efeitos colaterais e porque foi alertado sobre os riscos pelas notícias nas redes digitais.

\section{Considerações finais}

Na saúde pública, as fake news miram a vida. E apontam riscos para o corpo - ao enumerar as doenças relacionadas aos supostos efeitos de vacinas, por exemplo. Elas influenciam a conduta porque a sociedade e os indivíduos são motivados para a promoção da saúde. Segundo Sacramento, somos instados a nos proteger dos riscos que ameaçam nossos corpos e nossas crenças sob o discurso de promoção da saúde: "Num contexto de intenso apelo à responsabilização pelas escolhas saudáveis pelos indivíduos, não se vacinar pode ser 
menos um ato de descuido com a saúde do que de prevenção em relação aos riscos de efeitos adversos possíveis pela vacinação que são largamente explorados pelos movimentos antivacinação. Esse excesso de zelo diz respeito à intensa virtualização do risco, numa lógica hiperpreventista, mas também ao exercício do poder de definir a autonomia como condição da existência individual na contemporaneidade. Se o indivíduo é livre para escolher e responsável pelas suas escolhas e, portanto, pela sua saúde, ele pode inclusive preferir num dado campo de possibilidades de proteção deixar de se vacinar. Essa lógica está muito presente em grupos antivacinação presentes no Facebook”14.

Na combinatória de falsas afirmações, vemos emergir a desconfiança em três enunciadores fortes na área da saúde: o Estado, que regulamenta a vacinação; os médicos, que representam o campo do saber ou a expertise; e a indústria farmacêutica, que produz a vacina e representa a tecnologia ou o poder da ciência. As notícias falsas disputam o lugar de fala com o Estado, os experts e a ciência. Desacreditam a indústria farmacêutica e os profissionais da área médica, valorizando tratamentos alternativos para a manutenção da saúde. As fake news defendem a vida, quando se referem aos prejuízos à saúde causados pela vacina, ao mesmo tempo que colocam a vida em risco, quando conduzem o indivíduo a abandonar a imunização e, assim, manter-se suscetível a doenças.

Quanto mais forte a desconfiança nesses principais enunciadores, maior a força de convencimento das fake news. Temos, então, um discurso constrangendo o outro, dependendo do papel que desempenham na organização da sociedade. O conteúdo dos discursos nessa relação de poder importa menos do que a suposta verdade que ele produz. Para se entender de que forma as fake news enfrentam as narrativas consideradas oficiais na disputa pela verdade, cabe lembrar a reflexão de Foucault sobre a produção do que funciona como verdadeiro numa determinada sociedade: “A verdade é deste mundo; ela é produzida nele graças a múltiplas coerções e nele produz efeitos regulamentados de poder. Cada sociedade tem seu regime de verdade, sua política geral de verdade: isto é, os tipos de discurso que ela acolhe e faz funcionar como verdadeiros; os mecanismos e as instâncias que permitem distinguir os enunciados verdadeiros dos falsos, a maneira como se sancionam uns e outros, as técnicas e os procedimentos que são valorizados para a obtenção da verdade; o estatuto daqueles que têm o encargo de dizer o que funciona como verdadeiro ${ }^{41}$ ”.

Seguindo a linha de raciocínio de Nikolas Rose, sociólogo britânico, um novo papel para o 'Estado' se desenha a partir do início do século XXI, pois agora ele deve atuar por intermédio da ação de um grande número de autoridades e também de tecnologias complexas se quiser intervir na conduta de pessoas, atividades, ambientes e objetos distantes no tempo e espaço - como escolas, ruas, casas, teatros, prisões etc., com a finalidade de assegurar que resultados calculados sejam possíveis. Ocorre que esse tipo de 'ação a distância' depende, inevitavelmente, de uma variedade enorme de alianças e enlaces entre grupos de expertises diversas, critérios de julgamento e dispositivos técnicos que não pertencem ao aparato político tradicional. Como afirma Rose: "Isso gera uma heterogeneidade, uma contestabilidade e uma mobilidade intrínseca nas práticas para o governo da conduta. O 'Estado' não é mais a única força envolvida no governo de condutas e nem a mão invisível que deve orquestrar as estratégias e técnicas de médicos, advogados, religiosos, organizações comunitárias, grupos de pressão, grupos de campanha, grupos de parentes, cidadãos, pacientes etc.”42. Condutas que dependem de uma avaliação sobre o risco para a própria vida, acabam se tornando suscetíveis a discursos emitidos pelas mais variadas fontes, exatamente porque o Estado, em algum momento, passou a depender de uma variedade cada vez maior de atores para o exercício do governo dessas mesmas condutas. Essa pulverização dos atores com poder de enunciar a verdade acabou permitindo, como uma espécie de efeito colateral, que o discurso sobre o risco fosse apropriado numa complexa rede de disputa de interesses, sejam eles políticos, científicos, econômicos ou religiosos. As notícias falsas se inserem, justamente, nesse cenário pulverizado de enunciações, em que a relação entre o poder do enunciado e a conduta a ser obtida se resolve na própria força de convencimento do enunciado em si mesmo. A conhecida estratégia do Estado de associar a promoção da ideia de risco com determinadas condutas dos indivíduos acabou por fugir inteiramente ao controle. As fake news são a prova disso. 
Além de eficiente arma contra a vida, na área da saúde, as fake news representam muito mais que um fenômeno das mídias, embora se constituam como parte do processo comunicacional. Há muito tempo, elas alteram a conduta dos indivíduos. Inicialmente, atuavam por meio dos veículos de comunicação de massa, e agora na potência da multiplicação das redes digitais. A fabricação de notícias acompanha a civilização, com evidências amplamente comprovadas em momentos históricos como a operação do Nazismo, durante a campanha contra a comunidade judaica, e a Guerra Fria, na disputa pelo poder entre Estados Unidos e União Soviética. Assistimos ao uso das fake news como disputa de poder no Facebook durante a campanha presidencial nos Estados Unidos, em 2016, principalmente pelo então candidato e atual presidente Donald Trump, e no Brasil, em 2018, pelo então candidato e atual presidente do Brasil Jair Bolsonaro. Não à toa o emprego das notícias falsas levou os dois candidatos ao posto de mandatários de seus respectivos países, assim como a força das fake news, nas redes sociais, tem derrubado os índices de imunização no mundo inteiro, proporcionando o reaparecimento de doenças já erradicadas. São notícias fabricadas com a intenção de causar confusão ou o convencimento. Trata-se de ferramenta usada na disputa do poder por grupos que se apropriam da lógica de funcionamento das redes e dos aplicativos. Os posts apresentados neste artigo demonstram, parcialmente, de que forma essas falsas notícias empregam nossas crenças, medos e desejos com o objetivo de afetar nossa subjetividade e impor condutas por meio do convencimento sobre a verdade da nossa época.

\section{Referências}

1. Guimarães K. Vacinação em queda no Brasil preocupa autoridades por riscos de surtos e epidemias de doenças fatais [Internet]. BBC Brasil: 2017 ago 29. [Acesso em 2020 mar. 26]. Disponível em: https:// www.bbc.com/portuguese/brasil-41045273

2. Colluci C. Deixar de vacinar os filhos é ilegal no Brasil; falta mensagem [Internet]. Folha de S.Paulo (Grupo Folha). 2018 jun. 19 [acesso em 2020 mar. 14]:Análise. Disponível em: https://www1.folha.uol. com.br/cotidiano/2018/06/deixar-de-vacinar-filhos-e-ilegal-no-brasil-falta-mensagem.shtml

3. Entidade alerta para avanço das fake news sobre vacina: Opas alerta que falsas notícias circulam em redes sociais e aplicativos de mensagens, desencorajando as pessoas a se vacinarem [Internet]. Brasília, DF: Metrópoles; 2018 jul. 30 [acesso em 2020 mar. 14]. Disponível em: https://www.metropoles.com/ brasil/saude-br/entidade-alerta-para-avanco-das-fake-news-sobre-vacinas

4. Ministério da Saúde (BR). Dados e indicadores da Saúde [Internet]. Brasília, DF: O Ministério; 2020 [acesso em 2020 mar. 14]. Disponível em: http://portalms.saude.gov.br/dados-e-indicadores-da-saude

5. Organização Pan-Americana da Saúde (BR). Países da América devem tomar medidas para manter a pólio fora da região [Internet]. Brasília, DF: A Organização; 2018 out. 23 [acesso em 2020 mar. 14]; Disponível em: https://www.paho.org/bra/index.php?option=com joomlabook\&view=topic\&id=257

6. Silva T. As Razões da queda na vacinação [Internet]. Revista Fapesp (Brasil): 2018 ago. [Acesso em 2020 mar. 26]. Disponível em: https://revistapesquisa.fapesp.br/2018/08/17/as-razoes-da-queda-navacinacao/

7. OMS vê tragédia em aumento de $400 \%$ nos casos de sarampo na Europa [Internet]. BBC News Brasil (BBC Trust). 2018 fev. 20 [acesso em 2020 mar. 14]. Disponível em: https://www.bbc.com/portuguese/ internacional-43120990

8. Wakefield A. Retracted: MMR Vaccination and Autism [Internet]. The Lancet. 1999 set. 11 [cited 2020 mar. 26];354(9182):949-950. Available from: https://www.thelancet.com/journals/lancet/article/ PIIS0140-6736(05)75696-8/fulltext

9. BBC Brasil (Brasil). OMS vê tragédia em aumento de $400 \%$ nos casos de sarampo na Europa [Internet]. A BBC: 2018 fev. 20 [Acesso em 2020 mar. 26]. Disponível em: https://www.bbc.com/portuguese/ internacional-43120990

10. Idoeta PA. A história que deu origem ao mito da ligação entre vacinação e autismo [Internet]. BBC Brasil (Brasil). 2017 jul 24. [Acesso em 2020 mar. 26]. Disponível em: https://www.bbc.com/portuguese/ geral-40663622 
11. Jain A, Marshall J, Buikema A. Autism occurrence by MMR vaccine status among US children with older siblings with and without autism. ] Am Med Assoc [Internet]. 2015 Apr 21 [cited 2020 Mar 14];313(15):1534-40. Available from: https://jamanetwork.com/journals/jama/fullarticle/2275444

12. Hviid A, Hansen JV, Frisch M, Melbye M. The MMR vaccine is not associated with risk for autism. Ann Intern Med [Internet]. 2019 Apr 16 [cited 2020 Mar 14];170(8). Available from: https://annals.org/aim/ fullarticle/2727209/mmr-vaccine-associated-risk-autism

13. Foucault M. Microfísica do poder. São Paulo: Graal; 2013.

14. Sacramento I. A saúde numa sociedade de verdades. Rev Eletron Comun Inf Inov Saúde [Internet]. 2018 jan.-mar. [acesso em 2020 mar. 14];12(1):4-8. Disponível em: https://www.reciis.icict.fiocruz.br/ index.php/reciis/article/view/1514/2201

15. Arendt H. Origens do totalitarismo. São Paulo: Companhia das Letras; 1989.

16. Atlas da Notícia (Brasil). Estatísticas v.3.0 [Internet]. Brasil: O Atlas, 2020 fev. [Acesso em 2020 mar. 26]. Disponível em: https://www.atlas.jor.br/plataforma/estatisticas/

17. Ferrara LD. Comunicação, mediações, interações. São Paulo: Paulus; 2015.

18. Jenkins H. Cultura da convergência. São Paulo: Aleph; 2009.

19. Costa T. Quais são as redes sociais mais usadas no Brasil em 2019? [Internet]. São Paulo: Rock Content; 2019 set. 20 [acesso em 2020 mar. 14]. Disponível em https://rockcontent.com/blog/redes-sociaismais-usadas-no-brasil/https://rockcontent.com/blog/redes-sociais-mais-usadas-no-brasil/

20. Dose fracionada da vacina é suficiente para proteger contra a febre amarela: checagem. 2018 jan. 24 [citado em 2020 mar. 14]. In: Drauzio. Uol [Internet]. São Paulo: Grupo Folha; 2018. Disponível em: https://drauziovarella.uol.com.br/checagens/dose-fracionada-da-vacina-e-suficiente-para-protegercontra-a-febre-amarela-checagem

21. Piva JD. O que é verdade e mentira sobre o surto da febre amarela? Tire suas dúvidas. 2017 jan. 23 [citado em 2020 mar. 14]. In: Agência Lupa. Uol [Internet]. São Paulo: Grupo Folha; 2018. Disponível em: https://piaui.folha.uol.com.br/lupa/2017/01/23/o-que-e-verdade-e-mentira-sobre-a-febre-amarela/

22. Janeiro: Aos Fatos; 2018 jan. 23 [2020 mar. 14]. Disponível em: https://aosfatos.org/noticias/tres-fatossobre-casos-confirmados-distribuicao-e-mortes-de-febre-amarela/

23. Domingos R. Tomar própolis repele mosquito da febre amarela? Não é verdade! 2018 jan. 22 [citado em 2020 mar. 14]. In: Fato ou Fake?. G1 [Internet]. Rio de Janeiro: Grupo Globo; 2018. Disponível em: https://g1.globo.com/e-ou-nao-e/noticia/tomar-propolis-repele-mosquito-da-febre-amarela-nao-everdade.ghtml

24. Becker K. Sete boatos sobre a febre amarela que sempre enganam os menos informados [Internet]. [local desconhecido]: Boatos.org.; 2018 jan. 30 [citado em 2020 mar. 14]. Disponível em: https://www. boatos.org/saude/7-boatos-febre-amarela.html.

25. Lopes G. A vacina contra a febre amarela é um veneno mortal? [Internet]. [local desconhecido: E-Farsas; 2017 mar. 22 [acesso em 2020 mar. 14]. Disponível em: https://www.e-farsas.com/vacinacontra-febre-amarela-e-um-veneno-mortal.html.

26. Domingos R Receita natural imuniza contra a febre amarela ou cura a doença? Não é verdade. É ou Não é. 2018 jan. 19 [citado em 2020 mar. 14]. In: É ou não é?. G1 [Internet]. Rio de Janeiro: Grupo Globo; 2018. Disponível em: https://g1.globo.com/e-ou-nao-e/noticia/receita-natural-imuniza-contra-a-febreamarela-ou-cura-a-doenca-nao-e-verdade.ghtml

27. Ministério da Saúde (BR). Saúde Sem Fake News [Internet]. Brasília, DF: O Ministério; [2019?] [acesso em 2020 mar. 14]. Disponível em: http://saude.gov.br/fakenews

28. O que é febre amarela? [Internet]. Rio de Janeiro: Fiocruz; 2018 mar. 01 [acesso em 2020 mar. 14]. Disponível em https://portal.fiocruz.br/pergunta/o-que-e-febre-amarela

29. 12 mil dúvidas em um ano de combate às fake News [Internet]. Brasília, DF: Ministério da Saúde; 2019 ago. 27 [acesso em 2020 mar. 14]. Disponível em: http://www.saude.gov.br/noticias/agenciasaude/45719-12-mil-duvidas-em-um-ano-de-combate-as-fake-news

30. A ingestão de própolis ajuda a proteger contra a febre amarela? [Internet]. Rio de Janeiro: Fiocruz, Perguntas e Respostas sobre Febre Amarela; 2018 jan. 25. [2020 mar. 14]. Disponível em: https:// portal.fiocruz.br/pergunta/ingestao-de-propolis-ajuda-proteger-contra-febre-amarela 
31. Matsuki E. Própolis afasta mosquito da febre amarela e da dengue \#boato [Internet]. [local desconhecido]: Boatos.org.; 2018 jan. 21 [citado em 2020 mar. 14]. Disponível em: https://www. boatos.org/saude/propolis-mosquito-febre-amarela.html

32. Domingos R. Receita natural imuniza contra a febre amarela ou cura a doença? Não é verdade. 2018 jan. 19 [citado em 2020 mar. 14] In: É ou não é?. G1 [Internet]. Rio de Janeiro: Grupo Globo; 2018. Disponível em: https://g1.globo.com/e-ou-nao-e/noticia/receita-natural-imuniza-contra-a-febre-amarelaou-cura-a-doenca-nao-e-verdade.ghtml

33. The Ledger (EUA). Lakeland Woman Judi Roberts Who Had Rare Syndrome Dies [Internet]. Flórida, EUA: The Ledger, 2010 mai.11 [ Acesso em 2020 mar. 26]. Disponível em: https://www.theledger.com/ article/LK/20100511/News/608079312/LL

34. Sete em cada dez brasileiros acreditam em informações falsas sobre vacinação. Sociedade Brasileira de Imunizações [Internet]. São Paulo: SBIM, Notícias; 2019 nov. 13 [acesso em 2020 mar. 14] 13 de novembro de 2019. Disponível em: https://sbim.org.br/noticias/1139-sete-a-cada-dez-brasileirosacreditam-em-informacoes-falsas-sobre-vacinacao

35. Vacina da febre amarela é um veneno mortal. Pensa Brasil. 21 de março de 2017 [acesso em 2019 dez. 01]. Disponível em: https://pensabrasil.com/?s=febre+amarela.

36. Rio já tem 131 macacos mortos em todo o estado; $69 \%$ foram vítimas de ação humana [Internet]. Brasília, DF: Agência Brasil; 2018 jan. 25. [acesso em 2020 mar. 14]. Disponível em: http:// agenciabrasil.ebc.com.br/geral/noticia/2018-01/rio-ja-tem-131-macacos-mortos-em-todo-o-estado-69foram-vitimas-de-acao-humana

37. Ministério da Saúde (BR). Ministério da Saúde declara o fim do surto de febre amarela [Internet]. Brasília, DF: O Ministério, 2017 set. 06 [acesso em 2020 mar. 16]. Disponível em: https://www.saude. gov.br/noticias/agencia-saude/29502-ministerio-da-saude-declara-fim-do-surto-de-febre-amarela

38. A vacina contra a febre amarela possui mercúrio em sua fórmula? [Internet]. Rio de Janeiro: Fiocruz, Perguntas e Respostas sobre Febre Amarela; 2018 fev. 15 [acesso em 2020 mar. 14]. Disponível em: https://portal.fiocruz.br/pergunta/vacina-contra-febre-amarela-possui-mercurio-em-sua-formula.

39. Lira C. Enfermeira do HC diz que todos têm que tomar a vacina da febre amarela na cidade de São Paulo [Internet]. [local desconhecido]: Boatos.org.; 2018 jan. 19 [acesso em 2020 mar. 14]. Disponível em: https://www.boatos.org/saude/enfermeira-febre-amarela-sao-paulo.html.

40. Maciel C. São Paulo tem 21 mortes e 40 casos de febre amarela desde janeiro de 2017 [Internet]. Brasília, DF: Agência Brasil; 2018 jan. 12. [acesso em 2020 mar. 14]. Disponível em: http:// agenciabrasil.ebc.com.br/geral/noticia/2018-01/sao-paulo-tem-21-mortes-e-40-casos-de-febre-amareladesde-janeiro-de-2017.

41. Foucault M. Em defesa da sociedade. São Paulo: Martins Fontes; 2012.

42. Rose N. A política da própria vida: biomedicina, poder e subjetividade no século XXI. São Paulo: Paulus; 2007. 